\title{
The Scenographic (Re-) Turn: Figures of Surface, Space and Spectator in Theatre and Architecture Theory 1680-1980
}

Thea Brejzek

School of Design, University of Technology Sydney, Australia

Abstract

Three cultural 'crises', namely the $17^{\text {th }}$ century debate regarding the ontology of time and space, the passage into modernity in the early $20^{\text {th }}$ century, and the rise of postmodernism in the late $20^{\text {th }}$ century, are portrayed here as 'shifts' in the spatial theories and practices of theatre and architecture. Each shift necessarily evokes the question all over again as to how meaning is attributed and negotiated in the design of space. G.W. Leibniz's theoretical spatial model of the universe as much as Max Herrmann's notion of theatrical space, Adolf Loos' modernist struggle against the ornament and Robert Venturi's embracing of the 'hybrid and impure' elements of architecture have shown that the centre of theatre and architecture practice rests upon the negotiation between the spectator's perspectival viewing of the object or performance and its distinct spatial condition of both surface and volume. This paper is concerned with the origin, the metaphor and rhetoric of the 'scenographic' in a specific time period (1680-1980) and focuses on what might be called several 'crises' in the thinking about architectural and theatrical space.

The theater, in which the architecture serves as a possible background, a setting, a building that can be calculated and transformed into the measurements and concrete materials of an often elusive feeling, has been one of my passions. --Aldo Rossi $1979^{1}$

Since the first cultural 'turn' and with the subsequent establishment of cultural studies from the late 1950s onwards, every subsequent 'turn' has questioned existing methodologies and opened up new and formerly marginalised fields of research. The

${ }^{1}$ http://archidose.org/wp/1999/02/08/teatro-del-mondo (accessed 1 March 2015 
many cultural 'turns' have, over time, shifted the focus in the arts, social sciences, design and the humanities from looking at objects as representatives of a culture to the recognition of dynamic processes and actions as producing heterogeneous realities. In addition, interdisciplinarity came to be understood widely as producing new knowledge that had long been suppressed by disciplinary rigidity. This paper does not intend to identify a single scenographic turn in the way of suggesting a sharp 'epistemological rupture', ${ }^{1}$ but seeks out the shifts, the meandering paths and the articulations and re-articulations, in short: the re-turns of the 'scenographic' in the theories of architecture and theatre. It is evident that definitions and attributions of the 'scenographic' have, since Vitruvius' normative definition, oscillated between a spatial and perspectival understanding on the one hand (spatial representation) and a surface and decorative understanding (graphic representation) on the other.

For both theatre and architecture theory, the spatial and subsequent performative turn in particular have provoked a paradigmatic methodological shift toward interrogating space as being both a hegemonic and an interactive system between humans, form and the (built) environment.

Renzo Piano's 1983-1984 Prometeo Musical Space, a flexible acoustic space designed exclusively for a performance of Luigi Nono's experimental opera at the Venice Biennial and Frank Gehry's crumpled paper set for Don Giovanni at the Los Angeles Disney Hall in 2012 are other examples of successful collaborations between architecture and theatre.

It is only with the resultant ephemeral performance architectures and subsequent theoretical reflections that the notion of the 'scenographic' has come to encompass the totality of all material and immaterial elements that make up a performance or an environment. In the performative environments of productively 'blurred genres' (Geertz 1980, 165) between theatre and architecture, the discipline's $20^{\text {th }}$ century battles for dominance between the tectonic (structural, meaningful) in architecture and the scenographic (decorative, effect-producing) in theatre has simply evaporated.

The shift toward an understanding of space as social practice, as dynamic rather than static and political rather than neutral, significantly underpinned by the reception of the writings of French theorists Henri Lefebvre and Michel de Certeau, has led to the emergence of a wide range of collaborative practices between architects and theatre practitioners. From the 1990s onwards, collectives such as Berlin's 
Raumlabor and New York's Diller \& Scofidio and scenographers such as Bert Neumann at Volksbühne Berlin work between architecture and performance in ways in which spatial performativity is privileged and at times comes to replace the finality of built form.

Until the 1980s, however, the 'scenographic' had, within theatre and architecture theory, occupied a marginalized territory in one, and suffered from a contested attribution in the other. In architecture theory, the 'scenographic' had come to denote a provocation in its equation with 'to do with surface' in opposition to the tectonic. In theatre theory, the 'scenographic' as 'to do with performance design' clearly remained under-theorized when compared to the discipline's rigorous engagement with questions of the body, of image, and of dramatic representation.

\section{The Three Crises}

The debate between German philosopher G.W. Leibniz (1646-1716) and his contemporary, British physicist Isaac Newton (1642-1726/27), on the ontology of (time and) space might be considered the first spatial crisis. Analysing the leading terms in the work of Leibniz in the 1680s, we see how the figures of spectator, space and scenography (perspective) ${ }^{2}$ enable him to fully articulate his concept of relational space against Newton's substantivist notion of absolute space. Leibniz's perspectival concept of relational space marked a major scenographic shift through his synthesis of the spatial and the performative.

Within the modernist project, the positions of Austrian architect Adolf Loos (1870-1933) and German theatre scholar Max Herrmann (1865-1942), with their passionate calls for abstraction in architecture and theatre, can be identified as a second crisis. Loos' convoluted 1908 manifesto, Ornament is Crime and Herrmann's carefully crafted but equally emphatic 1931 essay, 'Das theatralische Raumerlebnis' ('The Theatrical Experience of Space'), show how the figures of surface, space and spectator strengthen their call against the representative spaces of the $19^{\text {th }}$ century and for the passage into modernity beyond their disciplines. Loos' position on surface is shown to have been misunderstood in later architectural debates that equated 'surface' with the 'scenographic' which carried a negative connotation. Herrmann's phenomenological focus in the discussion of theatrical spatial experience is shown to open up scenography ('Bühnenkunst') as a new field of research establishing theatre 
studies for the first time as an independent academic discipline in Germany. Loos' and Herrmann's positions stand for a second major shift in the thinking about space with the aim to drive spatial practice forward into modernity.

The third crisis, and the third shift, occurred in the wake of the articulations of the spatial (Soja 1989) and the performative turns (Austin 1962; Carlson 1996; Butler 2000) with an emerging convergence of theatre and architectural practice toward a performative aesthetics and the creation of scenographic environments. US architecture theorist Kenneth Frampton's vehement attacks on architect Robert Venturi's embracing of the hybrid, scenographic city are shown to be a defence of modernism against the evident rise of postmodernism and its formal eccentricities. Central to Frampton's rhetorically charged argument as well as to Venturi's notion of a new urbanism are, again, the figures of space, surface and spectator, and, again, the notion of the 'scenographic' frames the debate at either end of the spectrum.

The 1980 Venice Biennale that for the first time presented an independent Architecture Biennial running parallel to the longstanding International Theatre Festival $^{3}$ stands in this context for the programmatic and propositional convergence of theatre and architecture. Italian neorationalist architect Aldo Rossi's Teatro del Mondo, a temporary floating theatre designed for the 1980 Venice Architecture and Theatre Biennials serves as a playful yet potent symbol for a beginning reconvergence of theatre and architecture practice and for the desire for the performative to re-enter architectural discourse.

Figure 1: Aldo Rossi, Analogous, drawing on tracing paper, Fondazione Aldo Rossi/Canadian Centre for Architecture CCA

Scenography and the 'scenographic': Spatial Representation in Architecture and Theatre

The figures of surface, space and the spectator are central in the appropriation of the terms 'scenographic' and 'scenography' in both theatre and architecture. The oppositional notions of Vitruvius' description of scenography as perspective, namely 'scenography (perspective)' (Vitruvius 1907, 25), on the one hand, and the etymological origin of scenography as the writing on/painting (of) the skene ${ }^{4}$, on the other, serve as a terminological point of departure. 
I wish to show how considerations of the scenographic unvaryingly unfold the spatial discourse toward the productive questioning of conventionalized figures of space and surface, thus propelling this very discourse into the future. The practices of theatre and architecture meet in their modes of representation, in drawings, visualisations, animations, and model making, and differ greatly in their modes of realisation. The realisation of theatre does not comprise the material realisation of the model box, but encompasses beyond the stage design the entire mise en scène for the duration of the performance. Theatre thus is realised in the ephemeral, unrepeatable live performance. Architecture, on the other hand, is realised in the construction of an object and its materiality both of which might continue to undergo changes beyond and after construction through processes of decay, reuse or restoration. Where the architectural object itself is capable of performance, i.e. where it has been conceptualised and designed to interact with its environment and inhabitants (see Diller \& Scofidio's 2002 Blur Building, an artificial enterable cloud created from a base structure in the lake of Neufchatel), it engages with the staging of space in the creation of an architectural mise en scène.

The notion of performance or the performative, as a quality that belongs to either theatre or architecture and that creates its own realities through a new focus on the live production of space, has been a relatively recent development. Significantly, the spatial turn of the 1980s directed the disciplines' attention and focus towards space as a system of hegemonic and social relations in the same way that the performative turn had influenced both theatre and architecture toward an emphasis on the constructed, the self-referential and the unstable. Encouraged by the paradigmatic shifts of the performative and the spatial turns, contemporary theatre and performance theory have begun to position scenography as a transdisciplinary practice (Brejzek 2011) that attributes meaning to space (Collins and Nisbet 2010) both in and beyond the theatre (Aronson 2012). In direct opposition, the 'scenographic' in architectural theory, has been used primarily as a rhetorical device to condemn decorative elements (Frampton 1983) in favour of the modernist dictum 'Less is more' and, at the same time, to defend postmodernism's eclectic architectural language and hybrid forms (Venturi 1967). The articulation of a scenographic turn as a synthesis of the performative and the spatial turn thus seems long overdue.

\section{Plan and Perspective: G.W Leibniz' spatial model of the universe}


I wish to suggest that the performative and the spatial are shown side by side in rationalist philosopher G.W. Leibniz' model of the theodicy ('the best of all possible worlds'), where both aspects contribute to the understanding of man's position in the universe. Leibniz expands the Vitruvian term 'scenography' as 'perspective' to encompass both a spectator and the existence of different perspectives dependent on the spectator's (change of) position. The ability to employ different perspectives is what distinguishes man from God and comprises, in a wider reading, a performative act. On 15 February 1712, Leibniz wrote in the 'supplementary study' of his letter to the Jesuit scholar Bartholomew Des Bosse, ${ }^{5}$

\begin{abstract}
Si corpora sunt phaenomena, et ex nostris apparentiis aestimantur, non erunt realia: quia aliter aliis appareant. Itaque realitas corposum, spatii, motus, temporis, videtur consistere in e out sint phaenomena Dei, seu objectum scientiae visionis. Et inter corporum apparitionem erga nos et apparitionem erga deum discrimen est, quodammodo quod inter scenographiam (emphasis T.B.) et ichnographiam. Sunt enim scenographiae diversae pro spectatoris situ, ichnographia seu geometrica representation uncia est (emphasis: T.B): nempe Deus exacte res videt quales sunt secundum Geometricam veritatem: quanquam idem etiam scit quomodo quaeque res cuique alteri appareat, et ita omnes alias apparentias in se continent eminenter. (Leibniz 1712 in Look and Rutherford 2007,230 and 232.
\end{abstract}

If bodies are phenomena, and are judged by our appearances, they will not be real, since they will appear differently to others. Thus, the reality of bodies, space, motion, and time seems to consist in this: that they are the phenomena of God, that is, the object of his knowledge of vision. And the difference between the appearance of bodies with respect to us and their appearance with respect to God is in some way like the difference between a drawing in perspective and a ground plan (italics T.B). For whereas drawings in perspective (italics T.B.) differ according to the position of the viewer (emphasis T.B), a ground plan or geometrical representation is unique. God certainly sees things exactly such as they are according to geometrical truth, although likewise also knows how each thing appears to every other, and thus he contains in himself eminently all the other appearances. (Leibniz 1712, in Look and Rutherford 2007, 231 and 233) ${ }^{6}$

The Latin original and its translation into English are positioned side by side to highlight their differences in meaning. By translating 'scenography' as 'perspective in drawing', Look and Rutherford emphasize the two dimensionality of the surface upon which the perspective is constructed. Additionally, 'viewer' rather than 'spectator' (Leibniz' 'spectatori') suggests a passive onlooking. In this excerpt, however, as is clear from the Latin original, Leibniz argues the notion of relational space through the dynamic and performative method of perspective against the static method of the ground plan, thus carrying forward and extrapolating Vitruvius' three modes of representation, namely scenography (perspective), orthography (elevation), and ichnography (plan) ${ }^{78}$.

Accordingly, Leibniz refers to Vitruvius not in order to describe the methods and techniques to represent an object but rather to articulate the concept of the 
theodicy through a spatial model. Leibniz links 'perspective' with performative practices and projection techniques already in his playful essay Drôle de Pensée touchant une nouvelle sorte de REPRESENTATIONS (1695), where he outlines plans for an Academy of Games and a Theatre of Art and Sciences, to be experienced by the spectator in an ambulatory manner, strolling from room to room to view the exhibits, to gamble, to dance, to attend a performance.

Bring together the marionettes du Marmis and the Pygmies. Shadows might be added to these. Either on stage or at the ends near the spectators, where there are lights, and little wooden figures, so agitated that they will throw their shadow against the paper in very startling and magnified proportions. But in order to prevent this shadow world from appearing all on one plane, resort to perspectives might bring about diminishing sizes of shadows. (Leibniz in Wiener 1940, 239-240) ${ }^{9}$

From the 1680s onwards, Leibniz had developed a startlingly modern notion of space as possessing no substantial reality but rather presenting the 'order of the togetherness', defined by the relations of objects (bodies) in space at a particular time, against Newton's dominant notion of space as absolute and mechanistic. Leibniz's position is significant for a contemporary discussion of the 'scenographic', not simply for the fact that his relativist notion of space can be traced through to contemporary theories of relational space, ${ }^{10}$ but because his explication of understanding space is based on acts of observation. Thus the act of on-looking and the relative contingencies of such observation are articulated through the figure of the spectator.

Maintaining an explicit anti-Newtonian position on space, and developing a unique world of singular, multiple and overall perspectives, Leibniz repeatedly employs scenography (perspective) and ichnography (ground plan) as leading metaphors. In the letter to des Bosses, Leibniz posits that there are 'many scenographies' thus juxtaposing the Vitruvian definitions of scenography, the art of perspectival representation, and ichnography, the geometric groundplan of a building, and, in conclusion, linking 'man' to 'scenography' and 'God' to 'ichnography'. Here, as in several other of his writings, the philosopher constructs a spatial model of a world made up of God's overall perspective and the many different perspectival representations man is able to perceive - depending on his 'situation' as 'spectator'. 
As early as 1686 Leibniz uses the image of the 'spectator' to speak of the world as made up from a myriad of different perspectives, unified by one overall viewing point. In Section 14 of his Discour de Métaphysique he states,

Just as a number of spectators think they are seeing the same thing, and do in fact understand each other, even though each one sees and speaks according to his point of view. ${ }^{11}$

Only through communication afterwards can the spectators conclude that indeed they have seen the same thing and that there is a single perspective beyond the individual points of view. Leibniz posits the unified whole (the world) as a harmonious composition of scenographic and ichnographic methods and resultant realities - of the multitude of spectators' perspectives and the singular ground plan as seen from above - and in so doing, shows himself to be foremost a spatial thinker. Leibniz, in order to understand the world, argues through the differing modes of representation of the world. However he concludes by privileging architecture's 'master plan' and thus the bird's-eye perspective over the multiple perspectives of the singular monad. Within Leibniz' monadology there exist an infinite number of possible worlds of which God has chosen the best of all possible ones. The figure of the spectator allows Leibniz to join the communal act of looking with an individualistic, localised point of view. The spectator's gaze is individualistic and dynamic and the notion of the 'scenographic' acts to support his metaphor of looking upon the world as watching a performance that is constructed from multiple perspectives yet forming one entity.

\section{Abstraction and Experience: Adolf Loos' and Max Herrmann's modernist aesthetics}

The early modernist architect Adolf Loos, whose iconic buildings include the marble clad Viennese American Bar and the uncompromising austerity of the Villa Mueller in Prague, and Max Herrmann, the theatre scholar and founder of theatre studies in Germany, were equally passionate and impatient as to their respective disciplines' passage into modernity. Against architectural and theatrical falseness through decoration and the desire to imitate reality, both Loos and Herrmann posited spatial abstraction as formal and aesthetic ideals. While it is evident, that Herrmann's writings should be subject to a close reading related to scenography ('Raumkunst' in Herrmann's words), this is, at first sight, not the case for the work of the architect Loos who never engaged with the stage. Rather, Loos is significant in the context of 
'scenographic shifts' as his highly problematic but immensely influential 1908 manifesto 'Ornament and Crime' has provided a continuous source of ammunition for the late architectural modernists of the 1970s and 80s against the formal eccentricities and the perceived 'scenographic' character of postmodernist architecture. In his manifesto Loos writes that ornament is alien to the project of modernity and regards it as an anachronistic remnant in contemporary architecture and art. His emphatic attack on ornament is thus at the same time a passionate and uncompromising embrace of a modernity Loos saw emerging worldwide. To Loos, the future of the city lay in the eradication of ornamentation as well as colour.

We have outgrown ornament; we have fought our way through to freedom from ornament. See, the time is nigh, fulfilment awaits us. Soon the streets of the city will glisten like white walls. Like Zion, the holy city, the capital of heaven. Then fulfilment will come. (Loos 1908, 20)

Emphatically, Loos argues against ornament in the wider context of a cultural critique of his times and renders it sterile, unable to evolve.

As ornament is no longer organically related to our culture, it is no longer the expression of our culture. The ornament that is produced today bears no relation to us or any other human in the world at large. It has no potential for development. (Loos 1908, 20)

In Loos' own architecture, the rendering of the façade is characterised by a functional aesthetic that met with both praise and shock. Famously, his 1909 design for the Goldman \& Salatsch Building (also called the Looshaus) on Vienna's Michaelerplatz was labelled the 'house without eyebrows' as it did away with external windowsills. The emperor's residence was directly opposite and it is said that Emperor Franz Joseph had those windows of the Hofburg facing the Looshaus barred up so he would not have to see Loos' 'awful' building. The Looshaus treats the design of exterior and interior as inextricably linked, with complex variations of different ceiling heights, open and closed spaces, a method he called 'compression and expansion' of space. 
My architecture is not conceived by drawings, but by spaces. I do not draw plans, facades or sections... For me, the ground floor, first floor do not exist... There are only interconnected continual spaces, rooms, halls, terraces... Each space needs a different height... These spaces are connected so that ascent and descent are not only unnoticeable, but at the same time functional. (Loos 1930 np)

In an inspired analysis of Loos' Raumplan (spatial plan), the simultaneous planning of internal and external spaces defined by differing heights and volumes, architecture theorist and Derrida-scholar Andrew Benjamin argues against Loos' perceived surface treatment of the façade.

Surfaces create space. And yet, for Loos, spatiality is not just the work of surface. Integral to the system is the Raumplan. The latter can be defined as volumetric juxtaposition and interpenetration resulting in the creation of different volumetric conditions (Benjamin 2006, 26)

Benjamin articulates the misreading of the 'scenographic as surface' by earlier commentators, namely Kenneth Frampton in the 1980s through a new reading of the façade as surface. His radical interpretation of surface as a spatial condition rather than a two-dimensional add-on provocatively dissolves the rhetoric that had continued to surround an assumed emptiness of surface. Surface and space are no longer opposites but rather linked by Loos' integrative design principle of the 'spatial plan'. The architect's dilemma, of living in two clashing cultures, that of the 'ornament' that Loos relegates to the 19th century, and that of 'abstraction', is shared by eminent German theatre scholar Max Herrmann ${ }^{12}$ and characteristic of early modernity in the first decades of the $20^{\text {th }}$ century.

Twenty years after Loos' radical refusal of ornament, Herrmann condemns the shallowness of two-dimensional decoration in theatre, just as Loos had done for architecture. Reminiscent of Leibniz' notion of perspectival and dynamic space, Herrmann argues for theatrical space to comprise of a multitude of individual spatial perceptions and experiences. In his 1931 essay, 'Das theatralische Raumerlebnis' (The Theatrical Experience of Space') Herrmann writes: 
'.. there is no "theatrical experience of space", on the contrary there are only "theatrical experiences of space" ' (Herrmann 2006, 513, all Hermann translations by T.B.).

Herrmann investigates the phenomenon of theatre space as 'art space' (Herrmann 2006, 502), distinct from reality and immune to attempts of naturalistic imitation and he argues for theatre space to be defined and created by the 'performance of human movement in theatrical space' (509). The stage director moderates the 'trinity of all defining factors' (Herrmann 2006, 511) to create a performance: the author's stage directions, the actor's bodily experience of the stage, and the audience's subjective experiences of the space. Well before the spatial and performative turns, Herrmann posits theatre space as co-authored space and asserts a co-authored perception of theatrical space. Experience and perception of space, Herrmann argues, is what makes each performance a singular and non-repeatable event. In a methodological move that reaches far beyond the adoption of a 'spatial perspective' (Wihstutz 2012, 1) in the emerging field of theatre studies, Herrmann introduces a Husserlian perspective into the understanding of theatre space. When Husserl says, 'I do not have the possibility of distancing myself from my body, nor it from me' (Husserl 1959, 159) he describes a fundamental spatial unity of body and self. In such topological thinking, all experience is localized and space defined through the body's perception. Herrmann follows Husserl in the notion of the existence of a corporeality of space where spatial experience is invariably bound to bodily experience. He develops a phenomenology of the theatre space where both the actor's and spectator's experiences are localized in the 'here and now' of the performance, and where the perception of the theatre space occurs through the body's presence in the space it co-creates through its very presence.

' $\ldots$ if there has been something resembling a spatial turn in theatre studies, then it must refer to the founding of an autonomous discipline separate from literary studies, focusing on the performance and mise-en-scène of theatre instead of on the analysis of dramatic literature.' (Wihstutz 2012, 2) 
Space is the underlying principle in Herrmann's understanding of what constitutes theatre and performance and forms the central raison d'etre for the establishment of the new discipline of theatre studies in the German-speaking world.

Loos' desire for architectural abstraction and Herrmann's call for theatre to be understood through a spatial perspective meet in their refusal of decoration. Both link their spatial concepts closely to a cultural critique of the 19th century with the overall aim to drive the respective practices forward toward the complex 20th century project of modernity, a struggle that would last well into the 1960s, accompanied by powerful rhetoric from historicists and modernists alike. Significantly, the crisis of representation as seen in the early decades of the 20th century was a move away from surface (plane) to space (volume) and can be understood as a second, major shift in the history of spatial theory and practice. Whereas Herrmann argues for stage art to be spatial art, thus emphasizing the central task of scenography in the creation of theatre space, Loos' condemnation of the decorative is discussed here in order to understand the origin of the debate against ornament in architecture that led to the equation of decoration with scenography in the 1980s.

\section{From Venice to Las Vegas: Architecture as Scenography}

With Postmodernism, praised and critiqued as an architectural style that embraced theatricality and effect, the contested terms 'scenography' and the 'scenographic' reentered architectural theoretical discourse in the 1980s. The 'scenographic' came to embody a crisis, and a major shift in architectural thinking since modernism and the 'scenographic' in architecture continues to denote the ephemeral, narrative and symbolic qualities of a built structure.

As suggested earlier, Kenneth Frampton's polemic against what he perceived as scenographic elements in architecture remains a memorable testament to a misunderstood modernist purism and a misreading of Loos. To Frampton, the colourful, playful and eclectic facades of postmodernist architecture, rich with formal references and direct quotations were mere surface, superfluous and inauthentic and motivated by cynicism (Frampton 1983). Frampton understands the 'scenographic' not as inherently spatial (perspectival) but as a continuation of the painting of the skene with no purpose other than decoration. Frampton writes: 
By scenographically simulating the profiles of classical and vernacular and thereby reducing the architectonics of construction to pure parody, Populism tends to undermine the society's capacity for continuing with a significant culture of built form. (Frampton 1983, 293)

Frampton posits the result of a scenographic approach to architecture as 'parody' against the 'reality' of architectural construction. His own position can be seen as a modernist one based on 'critical regionalism' (Frampton 1983; Tzonis 1981), a critical approach to design that incorporates both local and global conditions, issues and influences, and an overarching concern for form and tectonics. Tectonics in architecture comprises the organization of material and structural forces into a meaningful whole. To Frampton, tectonics gives meaning to a building whereas scenography as its direct opposite renders a building devoid of meaning, creating a mere simulation. Frampton reaffirms Loos' rejection of the ornament as surface and in this context dismisses the work of a growing number of postmodern architects and curators such as Michael Graves and Paolo Borghesi who had adopted scenographic strategies as central to their practice.

In a groundbreaking project in 1967 that led the way towards an acceptance of the popular architecture of the city as a subject of research, architects Robert Venturi and Denise Scott Brown had, with a group of students, graphically notated the Las Vegas strip and proposed a typology of the character of the amusement complexes with their highly decorated facades, namely as 'sheds' or as 'decorated ducks' 13 . Venturi and Scott-Brown's notion of Las Vegas as a 'scenographic' city is understood here as a reinterpretation of the antique skene towards a hybrid urbanity with surfacefacades that operate as meaning-producing volumes. Along with their theoretical writings, the hybrid buildings of Robert Venturi, Michael Graves and Charles Jencks contributed to Frampton's outrage. Since Venturi, however, declared the whole of Las Vegas a 'scenographic and theatrical city', a distinct shift in architecture's relationship to the 'scenographic' can be detected.

To simplify, the main thing is that it went from the archetype of strip and sprawl to the scenography of Disneyland. Scenography is not necessarily bad - the Place des Vosges is scenographic, and architecture, in a sense does involve making scenes. (Venturi 2009, sp) 
To Venturi, façade and building, city and urban inhabitant, spectator, surface and space are linked in the ephemeral production of meaning with the theatre serving as the central point of reference.

Rossi's Teatro del Mondo, referring back to Venice's $18^{\text {th }}$ century floating theatres, operated both as a scenographic environment for the spectators on San Marco and as a theatre for the spectators within its structure, as they were gliding through the waters of the San Marco Basin. Significantly, Rossi's project points back to the Palladian tradition of the architect-scenographer, responsible for both theatre architecture and built stage design, giving equal consideration to both. Commissioned for the exhibition Venezia e lo spazio scenico in the framework of theatre director Maurizio Scaparro's revival of the Venice Carnival to be held all over the city during the 1980 Biennials, spatial design and performative action created an overall, temporary urban scenography that has become the blueprint for successive temporary stagings of cities worldwide. Rossi's practicable theatre could seat 250 spectators and was set on a pontoon. The twenty-metre-high wooden structure was both building and barque and recalled Venice's long history of ephemeral festivities as it floated in the basin of San Marco for the duration of the Biennale. The simplicity of its construction - wooden planks over metal scaffolding — referenced Venice's urban condition of a city built on water. From the balcony on the top floor of the Teatro, one could look out and see Venice floating by as if it were a theatre backdrop, and from the mainland the entire structure was perceived as a theatrical object against the urban scenography of the city.

...[O] $\mathrm{n}$ the subject of architecture, I have still a dream of great civil architecture; not the concordance of discords, but the city that is beautiful because of the wealth and variety it contains. I believe in the city of the future recomposed. In truth the recomposition does not seek a single, overall design but the liberty of a life of its own, a freedom of styles. A city that is free. (Rossi 1987, 13)

Influenced by the notion of the raft as well as Rossi's memories of the towers of his childhood region of Lombardy, the Teatro is a 'recomposition' of architectural influences unhindered by formal constraint. 


\section{Surface, Space and Spectator}

The spectator, as the subject of individual perception and experience, was a central figure in the articulation of Leibniz' and Herrmann's thinking. The figure of the decorated surface as a cultural icon of the past that needs to be surpassed drives Loos' practice and Herrmann's writing toward the abstraction of modernism. Frampton's emphatic defense of modernism against a perceived shallowness of postmodernism is heavily reliant on the figure of surface, and a convergence of theatre and architecture practice is evident in Venturi's notion of the city as theatre. In Rossi's Teatro, the spectator is the author of a complex spatial narrative that unfolds between the watching of the performance in the theatre and looking out from the moving structure toward the city as scenography. The floating Teatro del Mondo links the built object with the city and renders its inhabitants both spectators and participants. The ephemeral scenographies of Venice and Las Vegas symbolise the shift toward an activation and reinterpretation of history freed from modernist orthodoxy.

Rather than proving the existence or non-existence of 'scenographic turns' in the theories of architecture and theatre, I have argued that three cultural 'crises' between 1680 and 1980 shifted the disciplines' theories and practices of space. This discussion is framed by the Newton-Leibniz debate on time as absolute or relative, the passage into modernity through the rejection of ornament and decoration, and the eclecticism of postmodernism. In my reading of Leibniz, considerations of the 'scenographic' in his perspectival model of the universe (theodicy) represent a synthesis of the spatial and the performative and are highly influential for contemporary articulations of relational space. Loos' and Herrmann's passionate writings in favour of abstraction in architecture and theatre have been read as emphatic calls for the advance of the project of modernity in the first three decades of the twentieth century. Finally, I argue that the largely rhetorical debate between the positively connoted 'tectonic' and the negatively connoted 'scenographic' (as surface and decoration) by Frampton in the 1980s provokes the third 'shift' in which the practices in architecture and theatre converge in a 'blurring' (Geertz 1980) of genres. Resultant practices 
between theatre and architecture show a transdisciplinary understanding of the 'scenographic', and are active in the continued negotiation of the triad of space, surface and spectator in both the production of space and the production of meaning.

\section{References}

Aronson, Arnold. 2012. The Disappearing Stage. Prague: Theatre Institute.

Austin, John. 1962. How to do things with words. Cambridge: Harvard University Press.

Benjamin, Andrew. 2006. "Surface effects: Borromini, Semper, Loos." The Journal of Architecture, 11/1:1-35.

Bachelard, Gaston. 1967. La Formation del'esprit scientifique (Education of the scientific mind), Paris: Vrin.

Braghieri, Gianni. 1991. Aldo Rossi: Works and Projects. Barcelona: Editorial Gustavo Gili, S.A.

Brejzek, Thea. 2011. Expanding Scenography: On the Authoring of Space. Prague: Theatre Institute.

Butler, Judith. 2000. "Critically Queer", Identity: A Reader. London: Sage Publications. 223-290.

Carlson, Marvin. 1996. Performance: A Critical Introduction London: Routledge. 
Collins, Jane and Nisbet, Andrew. (eds) 2010. Theatre and Performance Design. A Reader in Scenography. London: Routledge.

Frampton, Kenneth. 1980. Modern Architecture. A Critical History, London: Thames \& Hudson.

Geertz, Clifford. 1980. "Blurred Genres. The Reconfiguration of Social Thought." The American Scholar, Vol 49, No 2 (Spring 1980), 165-179.

Herrmann, Max. 2006. "Das theatralische Raumerlebnis". Raumtheorie. Edited by Joerg Duenne and Stephan Guenzel, 501-515. Frankfurt: Suhrkamp Verlag. Originally published in Zeitschrift für Ästhetik und allgemeine Kunstwissenschaft 25 (1931): 152.

Husserl, Edmund. 1952/1989. Ideen zu einer reinen Phänomenologie und phänomenologischer Philosophie. Zweites Buch: Phänomenologische Untersuchungen zur Konstitution. The Hague: Martin Nijhoff.

Leibniz, G.W.1695. Drôle de Pensée, touchant une nouvelle sorte de représentations. http://fr.wikisource.org/wiki/Dr\%C3\%B4le de Pens\%C3\%A9e, touchant une nouv elle_sorte de repr\%C3\%A9sentations (accessed 5 February 2015).

Loos, Alfred. 1908. "Ornament and Crime”, in Programs and manifestos on $20^{\text {th }}$ century architecture, ed by Ulrich Conrads, Cambridge/Massachusetts: MIT Press 1971, 19-25.

Leibniz, G.W. 1907. Discour de métaphysique, Paris: F. Alcan.

Leibniz, G.W. 1988. Discourse on Metaphysics and related writings. Edited and translated, with an introduction, notes and a glossary, by R.N.D.Martin and Stuart Brown. Manchester and New York: Manchester University Press. 
Leibniz, G.W. 2007. The Leibniz - des Bosses Correspondence. Translated, Edited and with an Introduction by Brandon C. Look and Donald Rutherford. New Haven and London: Yale University.

Loos, A. 1930. 'I do not design...'. Shorthand record of a conversation in Pilsen.

Marci Vitruvii Pollionus. 1807. De Architectura. Libri Decem (1807).

Edited by Gottlob Schneider. Leipzig: Goeschen Verlagshaus

McMorrough, John. 2009. “On Billboards and Other Signs Around (Learning From) Las Vegas". In Relearning from Las Vegas, edited by Aron Vinegar and Michael J Golec, 129-146. Minneapolis: University of Minnesota Press.

Panofsky, Erwin. 1991. Perspective as Symbolic Form. New York: Zone Books.

Rossi, Aldo. 1987. Aldo Rossi Architect. Milan: Electa Spa - Milano

Soja, Edward. 1989. Postmodern Geographies: The Reassertion of Space in Critical Social Theory. London: Verso Press.

Venturi, Robert. 1966. Complexity and Contradiction in Architecture. New York: The Museum of Modern Art Press.

Vitruvius . 1931. On Architecture. Edited from the Harleian Manuscript 2767 and translated into English by Frank Granger, Vol 1, London: William Heinemann.

Wiener, Philip P. 1940. "Leibniz's Project of a Public Exhibition of Scientific Inventions". Journal of the History of Ideas. Vol. 1, No. 2 (Apr. 1940). 232-240.

Wihstutz, Benjamin 2012. "Introduction”. Performance and the Politics of Space.

Theatre and Topology, edited by Erika Fischer-Lichte and Benjamin Wihstutz, 1-15. London: Routledge. 
${ }^{1}$ Bachelard referred to the constant formation and subsequent tearing down of 'epistemological obstacles' in science as 'epistemological ruptures' (Bachelard 1967, 102).

${ }^{2}$ For Leibniz' use of the term 'scenografia' see Leibniz - De Bosses Correspondence in Look and Rutherford 2007 (Eds), p 230. For Leibniz' use of the term 'spectatori/spectateur' see Look and Rutherford 2007 and Leibniz 1907 and 1988.

3 The Biennale Teatro has been a biennial event since 1934.

${ }^{4}$ Skene, from ancient Greek skēnē, the wooden architectural structure and back wall of the antique Greek theatre, and from ancient Greek graphein, to write,

${ }^{5}$ Leibniz and Bartholomew des Bosses exchanged letters between 1706-1716 with a focus on the problem of the theodicy. In 1710 Des Bosses translated Leibniz's Essais de Théodicée into Latin.

${ }^{6}$ Look and Rutherford translate 'scenographia' as 'drawing in perspective'. The omission of the term 'scenography' and the reference to drawing as well as the translators' choice of the more general term of 'viewers' may initially seem to obscure my argument of Leibniz' dynamic concept of the spectator constructing cognition of the reality of phenomena through the physical act of 'perspective-taking'. It is however shown in relationship to Leibniz' Discour de Métaphysique from 1686 that the figure of the 'spectator' as an active agent plays an important role in Leibniz notion of the individuals' perception of the 'phenomena' that make up the world.

${ }^{7}$ Vitruvius $1807,1.2,12$

${ }^{8}$ Vitruvius links scenography to scene-painting, or, rather, as Erwin Panofsky points out, to 'scene-making' ('scenam fecit') in the preface to Book 7 of De Architectura. 'Namque primum Agatharchus Athenis, Aeschylo docente tragoediam, scenam fecit (emphasis T.B.), et de ea commentarium reliquit. (Vitruvius 1806, 7. Prefatio, 176).

9 'Mais a fin que les personnes des ombres ne paroissent pas toutes sur un même plan, la perspective pourra remedier, par la grandeur diminuante des ombres' in the French original (fr. Wikisource.org)

${ }^{10}$ See David Harvey, Space as a Key Word, paper for 'Marx and Philosophy Conference', 29.5.2004, London, 1-16, cited after Harvey, Social Justice and the City 2003:

"If we regard space as absolute it becomes a "thing in itself" with an existence independent of matter. It then possesses a structure, which we can use to pigeonhole or individuate phenomena. The view of relative space proposes that it be understood as a relationship between objects, which exists only because objects exist and relate to each other. There is another sense in which space can be viewed as relative and I choose to call this relational space - space regarded in the manner of Leibniz, as 
being contained in objects in the sense that an object can be said to exist only insofar as it contains and represents within itself relationships to other objects.'

Leibniz' concept of relational space has also been highly influential in physics, from Einstein's Relativity Theory to a relational approach to quantum physics by John Baez and Carlo Rovelli.

11 Nevertheless, it is very true that the perceptions or [qualities] b) of all substances correspond with each other, so that each, carefully following the particular reasons or laws it has observed, fits in with the other + in doing the same, just as when several people agree with each other to be at a particular place at a prearranged day, they can in fact do so if they wish +. + Now although they all express the same phenomena, + it does not follow form this that their *expressions should be perfectly similar: it is enough that they are proportionate to each other. In the same way several spectators think they have seen the same thing + and indeed agree with each other + , although each sees and speaks according to his point of view. (Leibniz in Martin and Brown in a 1988 English translation from the original French, 53-54.).

${ }^{12}$ Max Herrmann (born 1865 in Berlin and died 1942 in Theresienstadt) studied German philology and history in Freiburg, Goettingen and Berlin. His main work, Research in Medieval and Renaissance German Theatre History was published in 1914 and was already based on a theatre studies approach that looked at performance practice and history. A professor in Berlin since 1919, Herrmann became the Director of the first German Institute for Theatre Studies in Germany (together with Julius Petersen) in 1923. Herrmann lost his professorship in 1933 and in 1942 was deported together with his wife to the Theresienstadt concentration camp where he died. Max Herrmann's works have not yet been translated into English.

13 'We have distinguished in a previous article ('Learning from Las Vegas, or a significance for A\&P parking lots', Architectural Forum March 1968) between two types of heraldry in the commercial environment: the sign which is the building (for example the roadside duck, first brought to fame in Peter Blake's book) and the sign which fronts the building. [...] Our thesis is that most architects' buildings today are ducks: buildings where an expressive aim ahs distorted the whole beyond the limits of economy and convenience; and that this although an unadmitted one, is a kind of decoration, and a wrong and costly one at that.' Denise Scott Brown and Robert Venturi 1968, 48. 